\section{JURNAL}

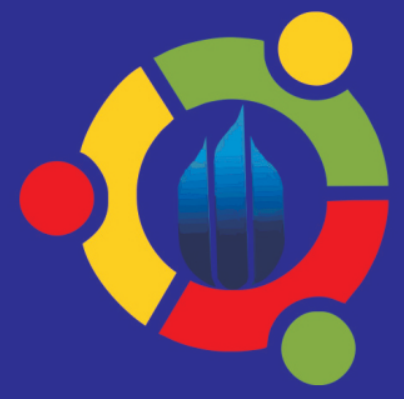

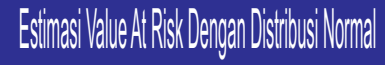

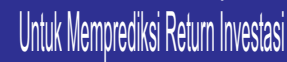

Hememenat

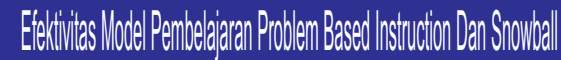

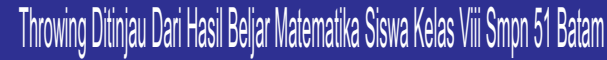

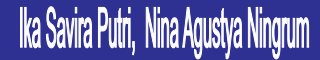

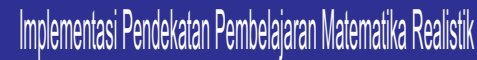

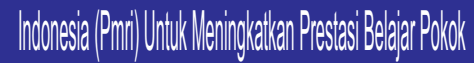

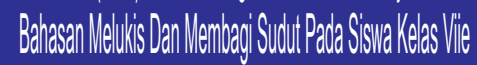
Smplogenil Seilegan

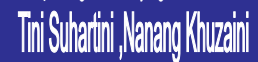

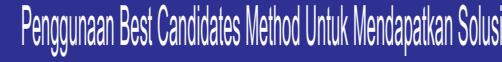

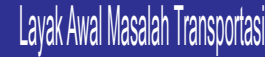

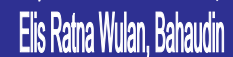

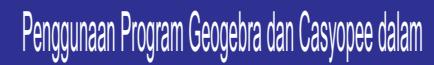

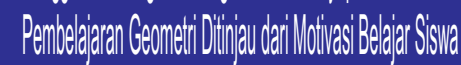

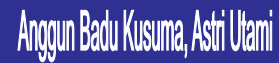

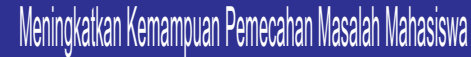

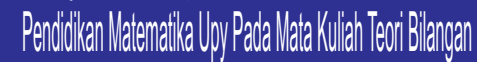

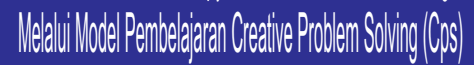
sistecanteningsin

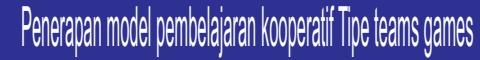

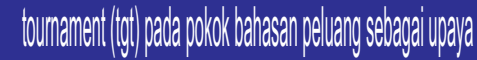

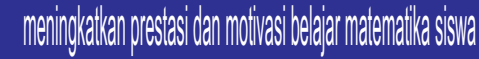

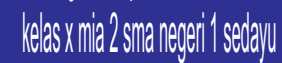
Numeaniciaten

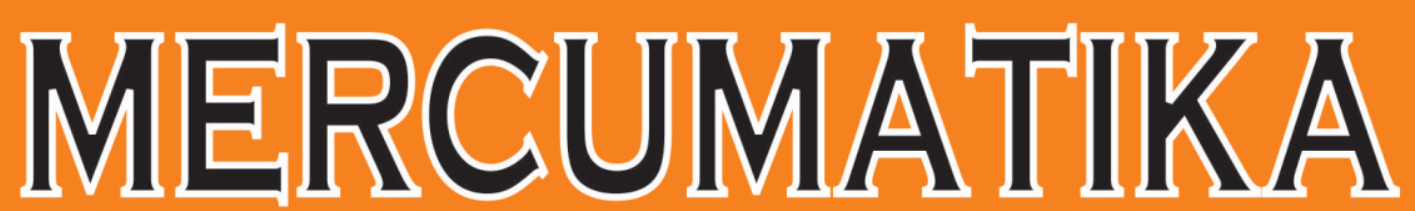

Jurnal Penelitian Matematika dan Pendidikan Matematika

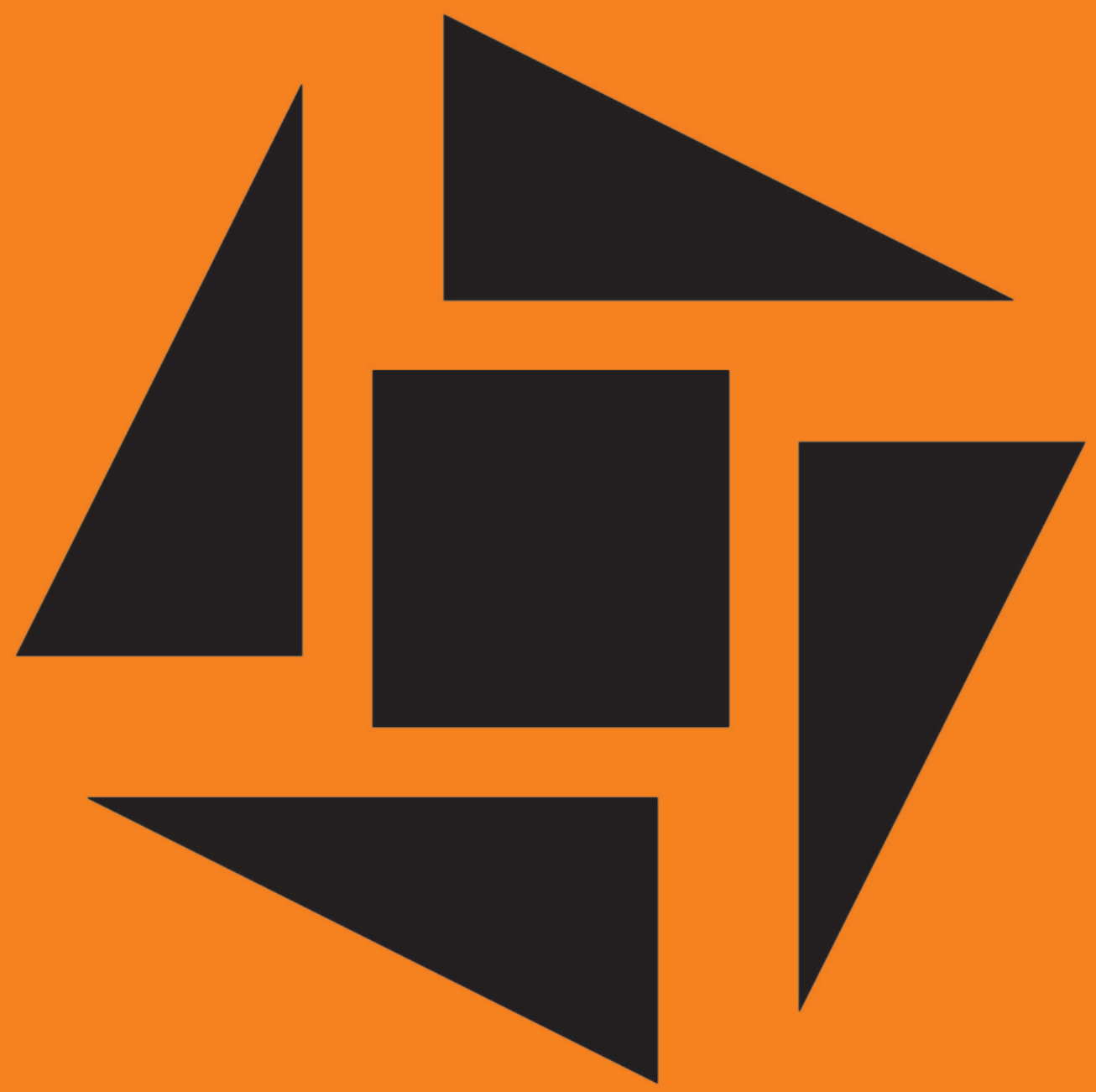

PROGRAM STUDI PENDIDIKAN MATEMATIKA FAKULTAS KEGURUAN dan ILMU PENDIDIKAN UNIVERSITAS MERCU BUANA YOGYAKARTA 


\title{
PEMIMPIN REDAKSI
}

Heru Sukoco, S.Si., M.Pd

SEKRETARIS REDAKSI

Isna Khalifa, M.Sc

Muhammad Irfan Rumasoreng, M.Pd

DEWAN REDAKSI

Prof. Dr. Rusgianto H.S., M.Pd (Universitas Negeri Yogyakarta)

Dr. Sugiman (Universitas Negeri Yogyakarta)

Dr. Ibrahim, M.Pd (Universitas Sunan Kalijaga Yogyakarta)

Nuryadi, S.Pd.Si., M.Pd

\author{
ADMINISTRASI DAN SIRKULASI \\ Tri Andi, S.T \\ ALAMAT REDAKSI \\ Universitas Mercu Buana Yogyakarta \\ Jalan Wates km. 10 \\ Yogyakarta 55753 \\ Telpon (0274) 6498212 pesawat 145 \\ Fax (0274) 6498213 \\ http://ejurnal.mercubuana-yogya.ac.id \\ Email: jurnal.umby@gmail.com
}

Jurnal Mercumatika (JM) diterbitkan oleh Unit Publikasi Ilmiah \& HaKI

Universitas Mercu Buana Yogyakarta, Merupakan wahana bagi dosen, mahasiswa, guru, dan juga praktisi pendidikan untuk menampilkan karya ilmiahnya, baik berupa hasil penelitian maupun kajian artikel hasil penelitian bidang pendidikan matematika dan matematika.

JM terbit dua kali setahun.

Redaksi menerima naskah yang belum pernah dipublikasikan. Pedoman penulisan naskah untuk JM tercantum pada bagian akhir jurnal ini.

Surat-menyurat mengenai artikel yang akan diterbitkan, langganan, keagenan dll, dialamatkan langsung ke alamat redaksi. 


\section{DAFTAR ISI}

Dewan Redaksi.

i

Kata Pengantar.

Daftar Isi

Estimasi Value At Risk Dengan Distribusi Normal Untuk Memprediksi Return Investasi

Hermansah.

Efektivitas Model Pembelajaran Problem Based Instruction Dan Snowball Throwing Ditinjau Dari Hasil Beljar Matematika Siswa Kelas Viii Smpn 51 Batam

Ika Savira Putri, Nina Agustya Ningrum.

Implementasi Pendekatan Pembelajaran Matematika Realistik Indonesia (Pmri) Untuk Meningkatkan Prestasi Belajar Pokok Bahasan Melukis Dan Membagi Sudut Pada Siswa Kelas Viie Smp Negeri I Seyegan

Tini Suhartini ,Nanang Khuzaini.

Penggunaan Best Candidates Method Untuk Mendapatkan Solusi Layak Awal Masalah Transportasi

Elis Ratna Wulan, Bahaudin

Penggunaan Program Geogebra dan Casyopee dalam Pembelajaran Geometri Ditinjau dari Motivasi Belajar Siswa

Anggun Badu Kusuma, Astri Utami

Meningkatkan Kemampuan Pemecahan Masalah Mahasiswa Pendidikan Matematika Upy Pada Mata Kuliah Teori Bilangan Melalui Model Pembelajaran Creative Problem Solving (Cps)

siska candra ningsih.

Penerapan model pembelajaran kooperatif Tipe teams games tournament (tgt) pada pokok bahasan peluang sebagai upaya meningkatkan prestasi dan motivasi belajar matematika siswa kelas $x$ mia 2 sma negeri 1 sedayu

Nurmahmidah. 


\title{
Implementasi Pendekatan Pembelajaran Matematika Realistik Indonesia (Pmri) Untuk Meningkatkan Prestasi Belajar Pokok Bahasan Melukis Dan Membagi Sudut Pada Siswa Kelas Viie Smp Negeri I Seyegan
}

\author{
Tini Suhartini ${ }^{1}$, Nanang Khuzaini ${ }^{2}$ \\ Prodi Pendidikan Matematika UMB, \\ Yogyakarta, Universitas Mercu Buana Yogyakarta \\ email:tinibeut@gmail.com ${ }^{1}$
}

\begin{abstract}
Abstrak
Penelitian ini bertujuan: (1) untuk mendeskripsikan pelaksanaan pembelajaran matematika dengan pendekatan Pembelajaran Matematika Realistik Indonesia (PMRI) dalam upaya meningkatkan prestasi belajar siswa kelas VII E SMP Negeri 1 Seyegan (2) mendeskripsikan peningkatan prestasi belajar siswa dalam pembelajaran matematika siswa kelasVII E SMP Negeri 1 Seyegan melalui pendekatan Pembelajaran Matematika Realistik Indonesia (PMRI). Penelitian ini merupakan penelitian tindakan kelas yang dilaksanakan secara kolaboratif dengan guru. Pengumpulan data menggunakan lembar observasi, dan soal evaluasi tiap siklus. Penelitian dilakukan dalam dua siklus, pelaksanaan siklus I diperoleh rata-rata nilai prestasi belajar siswa sebesar 83,00 \%, pada siklus II diperoleh nilai prestasi belajar siswa sebesar 93, 65\%. Dengan demikian pendekatan PMRI dapat meningkatkan prestasi belajar siswa.
\end{abstract}

Kata Kunci: Pembelajaran Matematika Realistik Indonesia (PMRI), Prestasi

Belajar, Mata pelajaran Matematika

The Implementation Of Indonesia Realistic Mathematics Learning Approach (Irml) To Increase Learning Acchievement In The Discussion Painting And Corner Splitting Subject On The Students Grade Viie Smp Negeri I Seyegan

\begin{abstract}
The goals of this research are: (1) To describe the implementation of mathematics learning with realistic mathematics learning approach Indonesia (PMRI) in efforts to improve learning achievement of students in grade VII E SMP Negeri 1 Sayegan (2) describe the improvement of student achievement in mathematics graders VII E SMP Negeri 1 Sayegan through a realistic approach to learning mathematics Indonesia (PMRI). This research is a classroom action research conducted collaboratively with teachers. Subject of research is 32 students in grade VII E SMP Negeri 1 Sayegan. Collecting data using observation sheets, and about the avaluation of each cycle. The study was conducted in two cycles, the implementation of the first cycle obtained an average value of student achievement amounted to $83.00 \%$, the second cycle obtained value student achievement by 93, 65\%. Thus PMRI approach can improve student achievement.
\end{abstract}

Keywords: Implementation Indonesia Mathematics Realistic Learning Approach

(IMRL), learning achievement, mathematics Subjects.

\section{Pendahuluan}

Tujuan nasional di dalam pembukaan Undang-undang Dasar 1945 antara lain adalah memajukan kesejahteraan umum dan mencerdasakan kehidupan bangsa. Dalam UU RI tentang Sistem Pendidikan Nasional (UUSPN) No. 20 tahun 2003 tercantum bahwa pendidikan nasional berfungsi mengembangkan kemampuan dan membentuk watak serta peradaban bangsa yang bermartabat dalam rangka mencerdaskan kehidupan bangsa, bertujuan untuk berkembangnya potensi peserta didik agar menjadi manusia yang 
beriman dan bertaqwa kepada Tuhan Yang Maha Esa, berakhlak mulia, sehat, berilmu, cakap, kreatif, mandiri, dan menjadi warga negara yang demokratis serta bertanggungjawab (UU Sisdiknas, 2003, p.3).

Kualitas dari pendidikan nasional salah satunya dapat dilihat dari hasil belajar siswa di setiap jenjang pendidikan baik hasil belajar siswa dalam ranah, kognitif, afektif, maupun psikomotor. Indikator hasil belajar kognitif biasa disebut sebagai prestasi belajar siswa di sekolah. Oleh karena itu, upaya peningkatan mutu dari pendidikan nasional salah satunya dapat ditempuh dengan meningkatkan prestasi belajar siswa di setiap jenjang pendidikan. (Hananto Wibowo, 2010, p.2).

Guru sebagai fasilitator dalam kegiatan pembelajaraan memegang peranan penting dalam meningkatkan kualitas siswa dan prestasi belajar siswa terutama dalam belajar matematika. Guru harus benarbenar memperhatikan, memikirkan dan sekaligus merencanakan proses pembelajaran yang menarik bagi siswa, agar siswa semangat dalam belajar dan mau terlibat aktif dalam proses pembelajaran, sehingga pembelajaran tersebut menjadi efektif.

Menurut Gravemeijer (Armanto, 2002, p.30-33) Pembelajaran Matematika Realistik Indonesia (PMRI) merupakan salah satu langkah yang dapat diambil agar matematika tidak terkesan sulit. Salah satu hal yang khas dari pendekatan Pembelajaran Matematika Realistik Indonesia (PMRI) yaitu memiliki karakteristik: memakai konteks dunia riil, menggunakan model, menggunakan kontribusi siswa, interaktif dan keterkaitan dengan materi atau bidang lain. Menurut Hans Freudental, pencetus ide pendidikan matematika realistik, bahwa matematika sebagai suatu bentuk aktifitas manusia, bukan sekedar objek yang harus ditransfer dari guru ke siswa. Konsep Pendekatan Matematika Realistik Indonesia (PMRI) sesuai dengan tuntutan pembelajaran saat ini yaitu agar siswa membangun pengetahuannya sendiri. Siswa bukan lagi penerima informasi-informasi yang disampaikan guru, melainkan siswa sebagai subjek belajar yang membangun pengetahuan berdasarkan pengalaman yang dialaminya dalam proses pembelajaran. Siswa tidak bisa dianggap sebagai penerima pasif dari pembelajaran matematika, namun pembelajaran matematika hendaknya memberikan kesempatan bagi siswa untuk menemukan kembali pengetahuan matematika dengan memanfaatkan berbagai kesempatan dan situasi nyata yang dialami siswa (Fadjar Shadiq, 2012, p.8).

Berdasarkan uraian diatas, maka dalam upaya mencapai kearah tujuan penelitian ini, yaitu untuk meningkatkan prestasi belajar siswa dalam pembelajaran matematika, maka penulis berkolaborasi dengan guru mata pelajaran melakukan penelitian tindakan kelas dengan judul penelitian "Implementasi Pendekatan Pembelajaran Matematika Realistik Indonesia (PMRI) Untuk Meningkatkan Prestasi Belajar Pokok Bahasan Melukis dan Membagi Sudut Pada Siswa Kelas VII E SMP Negeri I Seyegan”.

\section{Landasan Teori}

Menurut Gagne (Agus Suprijono, 2009, p.2), belajar adalah perubahan disposisi atau kemampuan yang dicapai seseorang melalui aktivitas. Perubahan disposisi tersebut bukan diperoleh langsung dari proses pertumbuhan seseorang secara ilmiah.

Senada dengan itu Muhammad Irham (2013, p.116) menjelaskan belajar merupakan sebuah proses yang dilakukan individu untuk memperoleh pengetahuan dan pengalaman baru yang diwujudkan dalam bentuk perubahan tingkah laku yang relatif permanen dan menetap disebabkan adanya interaksi individu dengan lingkungan belajarnya.

Pembelajaran menurut Dimyati dan Mujiono (Syaiful Sagala, 2003, p.62) adalah kegiatan guru secara terprogram 
dalam desain intruksional, untuk membuat siswa belajar secara aktif, yang menekankan pada penyediaan sumber belajar

Menurut R. Soedjadi (2000, p.11) matematika yaitu sebagai cabang ilmu pengetahuan yang terorganisir secara logik yang membahas tentang bilangan, kalkulasi, penalaran logis, fakta kuantitatif, ruang dan aturan-aturan yang ketat. Freudental dalam A. M Slamet Soewandi (2005, p.24) menyatakan bahwa matematika adalah suatu aktivitas manusia. Matematisi menemukan konsep matematika dengan berbuat, melakukan refleksi terhadap tindakan (aktivitasnya) lalu menemukan hasilnya berupa konsepkonsep, sifat-sifat konsep, hubungan antara konsep-konsep, aturan-aturan, dan prinipprinsip lalu mengkontruksinya.

Pembelajaran dan pemahaman konsep matematika dapat di awali secara induktif melalui pengalaman peristiwa nyata atau intuisi. Kegiatan dapat dimulai dengan beberapa contoh atau fakta yang teramati, membuat daftar sifat yang muncul (sebagai gejala), memperkirakan hasil baru yang diharapkan, yang kemudian dibuktikan secara deduktif. Penerapan cara kerja matematika diharapkan dapat membentuk sikap kritis, kreatif jujur, dan komunikatif pada siswa. (Aqilah, 2012, p.23)

Jadi dapat disimpulkan bahwa pembelajaran matematika adalah proses interaksi sosial antara guru dan siswa yang melibatkan pengembangan pola pikir dan melatih siswa untuk dapat lebih berfikir logis dan sistematis, berpusat pada kegiatan siswa dan bukan berpusat pada kegiatan guru mengajar.

\section{Pembelajaran Matematika Realistik Indonesia}

Menurut Van den Heuvel-Panhuizen (Aryadi Wijaya, 2012, p.20) Pembelajaran Matematika Realistik adalah suatu pendekatan pembelajaran matematika yang berkembang pertama kali di Belanda. Kata "realistik" sering disalah artikan sebagai "real-world", yaitu dunia nyata. Banyak pihak yang menganggap bahwa pendidikan matematika realistik adalah suatu pendekatan pembelajaran matematika realistik yang harus selalu menggunakan masalah sehari-hari. Penggunaan kata "realistik" sebenarnya berasal dari bahasa Belanda "zich realiseren" yang berarti "untuk dibayangkan" penggunaan kata realistik tersebut tidak sekedar menunjukkan adanya suatu koneksi dunia nyata (real-word) tetapi lebih mengacu pada penekanan penggunaan situasi yang bisa dibayangkan (imagineable) oleh siswa.

Pembelajaran Matematika Realistik Indonesia (PMRI sebagai adaptasi dari Realistic Mathematic Education (RME) dalam konteks ke Indonesiaan mengusung landasan filosofis, perinsip dan karakteristik yang tepat sama dengan Realistic Mathematic Education (RME), namun berbeda pada beberapa hal karena konteks, budaya, sistem sosial, dan alam yang berbeda. Terkait dengan aktivitas matematisasi dalam belajar matematika, Freudenthal (Van den Heuvel Panhuizen, 1996, p.11) menyebutkan dua jenis matematisasi, yaitu matematisasi horizontal dan vertikal dengan penjelasan sebagai berikut "Horizontal mathematization involves going from the world of life into the world of symbol, while vertical mathematization means moving within the world of symbol". Pernyataan tersebut menjelaskan bahwa matematisasi horizontal meliputi proses transformasi masalah nyata/sehari-hari ke dalam bentuk simbol, sedangkan matematisasi vertikal merupakan proses yang terjadi dalam lingkup simbol matematika itu sendiri.

Gravemeijer (1994, p.93) mengemukakan bahwa dalam proses matematisasi horizontal, siswa belajar mematematisasi masalah-masalah kontekstual. Pada mulanya siswa akan memecahkan masalah secara informal (menggunakan bahasa mereka sendiri). Kemudian setelah beberapa waktu dengan proses pemecahan masalah yang serupa 
(melalui simplifikasi dan formalisasi), siswa akan menggunakan bahasa yang lebih formal dan diakhiri dengan proses siswa akan menemukan suatu algoritma. Proses yang dilalui siswa sampai menemukan algoritma disebut matematisasi vertikal

Menurut Van den Heuvel-Panhuizen (Ariyadi Wijaya, 2012, p.20). Karakteristik Pembelajaran Matematika Realistik adalah menggunakan konteks "dunia nyata", penggunaan model, pemanfaatan hasil konstruksi siswa, interaktivitas dan keterkaitan.

Berdasarkan uraian diatas mengenai pembelajaran dengan Pendekatan Pembelajaran Matematika Realistik Indonesia (PMRI) yaitu suatu pendekatan yang menggunakan situasi dunia nyata atau suatu konteks sebagai titik tolak dalam belajar matematika. Pada tahap ini siswa melakukan aktiviitas horizontal. Maksudnya siswa mengorganisasikan masalah dan mencoba mengidentifikasi aspek matematika yang ada pada masalah tersebut. Kemudian, dengan menggunakan matematika vertikal yaitu siswa tiba pada pembentukan konsep.

\section{Metode Penelitian}

Penelitian ini dilaksanakan dengan metode penelitian tindakan kelas (PTK). Dalam penelitian digunakan setting kelas dan setting kelompok dimana data diperoleh pada saat proses pembelajaran yang terjadi didalam kelas dan kelompok. Kelas VII E ini dipilih atas dasar kesepakatan peneliti dan guru bidang studi matematika kelas VII E. Sumber data utama dalam penelitian ini adalah siswa, guru, hasil observasi selama pelaksanaaan tindakan kelas, catatan lapangan, hasil angket belajar siswa, hasil wawancara dengan siswa dan guru, hasil tes tertulis, dan data tambahan berupa dokumentasi foto.

Perangkat pembelajaran yang digunakan adalah Rencana Proses Pembelajaran (RPP), Lembar Kegiatan Siswa (LKS), kuis, Lembar evaluasi.
Desain penelitian ini menggunakan desain penelitian tindakan kelas yang dikembangkan oleh Kemmis dan Mc Taggart. (Zainal Aqib, 2008, p.14). Model visualisasi bagan yang disusun oleh Kemmis dan Mc Taggart adalah sebagai berikut.

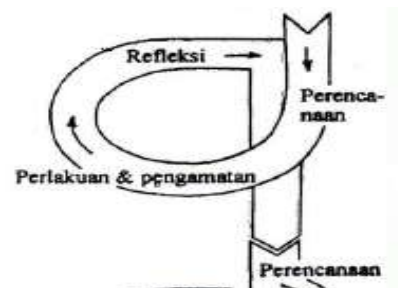

Gamabar 1: Desain Penelitian

Tindakan Kelas menurut Kemmis dan an Mc Taggart

n penelıtıan inı mencakup empat ıangkan, yaitu: (1) perencanaan (planing), (2) tindakan (acting), (3) pengamatan (observing), (4) refleksi (reflecting).

Secara rinci prosedur penelitian tindakan diatas dapat dijabarkan sebagai berikut:

1. Siklus I

a. Perencanaan

Adapaun kegiatan yang dilaksanakan dalam tahap perencanaan pada siklus I meliputi:

a) Menyusun perangkat pembelajaran (RPP) dengan materi melukis dan membagi sudut dengan menggunakan metode pembelajaran Pendekatan Mmatematika Realistik Indonesia (PMRI).

b) Membuat lembar observasi pembelajaran guru dan siswa.

c) Membuat lembar lembar kerja siswa (LKS) beserta kunci jawabanya.

d) Menyiapkan soal untuk kuis

e) Merencanakan pembentukan kelompok

f) Menyiapkan soal evaluas

b. Tindakan atau acting 
Tahap tindakan dalam penelitian meliputi:

a) Guru membuka pelajaran dengan salam kepada siswa.

b) Guru melakukan pengecekan (absensi) kehadiran siswa.

c) Guru menjelaskan kepada siswa mengenai metode pembelajaran dengan menggunakan pendekatan matematika realistik Indonesia (PMRI).

d) Guru menyampaiakan tujuan dari pembelajaran yang akan dilaksanakan.

e) Sebelum melakukan tindakan, sebelumnya guru memberikan lembar pretest untuk mengukur sejauh mana kemampuan siswa.

f) Guru menyampaikan sedikit materi kepada siswa.

g) Guru membagi siswa dalam 8 kelompok dimana tiap kelompoknya terdiri dari 4 orang.

h) Membagi lembar kegiatan siswa untuk membantu siswa lebih memahami materi yang diajarkan dengan menggunakan alat peraga.

i) Guru memberikan kesempatan kepada semua kelompok untuk mempersentasikan hasil diskusi dai depan kelas.

j) Guru dan siswa bersamasama mengevaluasi dan menyimpulkan hasil belajar.

c. Pengamatan (Observasi)

Pada saat melakukan observasi peneliti melakukan kegiatan, diantaranya:

a) Peneliti mengamati proses belajar siswa pada siklus I

b) Mengamati siswa ketika mengerjakan LKS dan kuis. c) Mengamati hasil evaluasi (tes).

d) Mengamati keberhasilan dan hambatan-hamabatan yang dialami ketika proses pembelajaran yang belum sesuai dengan harapan penelitian.

e) Mengamati dan mencatat siswa yang aktif, berani bertanya kepada guru, atau berani menjawab pertanyaan dari teman yang belum paham dan berani mengerjakan tugas di papan tulis.

d. Refleksi

Adapun refleksi pada siklus I yakni:

a) Secara kolaboratif guru dan peneliti menganalisis dan mendiskusikan hasil dari pengamatan. Selanjutnya membuat suatu refleksi dari penelitian mana yang perlu diperhatikan dan mana yang perlu adanya perbaikan pada siklus II nantinya.

b) Membuat simpulan sementara terhadap pelaksanaan siklus I

2. Siklus II

Pelaksanaan siklus II secara teknis sama seperti pelaksanaan siklus I. Pada siklus II pokok bahasan yang diajarkan yaitu mengenai pokok bahasan membagi sudut. Semua kegiatan yang dilakukan merupakan perbaikan dari siklus I, terutama berdasarkan hasil refleksi pada siklus I, yakni sebagai berikut:

a) Perencanaan

Meninjau kembali rencana pembelajaran yang disiapkan untuk siklus 2 dengan melakukan revisi sesuai hasil siklus I.

b) Pelaksanaan 


\begin{abstract}
Guru melaksanakan pembelajaran sesuai dengan RPP yang telah disiapkan. Adapun langkah-langkah pembelajaran yang dilaksanakan pada siklus II tidak jauh berbeda dengan siklus I. Dalam siklus 2 materi yang disampaikan yaitu pokok bahasan membagi sudut.

c) Pengamatan

Peneliti melakukan pengamatan yang sama seperti pada siklus I.

d) Refleksi

Pada tahap ini peneliti dan guru kelas mendiskusikan hasil pengamatan untuk mendapat simpulan. Setelah berakhirnya siklus II diharapkan penerapan pendekatan pembelajaran matematika realistik Indonesia (PMRI) pada materi melukis dan membagi sudut dapat meningkatkan prestasi belajar pada siswa kelas VII E SMP Negeri I Seyegan.
\end{abstract}

\section{Tehnik Pengumpulan Data}

Dalam penelitian ini data diperoleh langsung oleh peneliti dengan observasi, wawancara, dokumentasi, catatan lapangan, dan tes tertulis.

\section{Validasi data}

Analisis data yang digunakan adalah analisis data deskriptif kualitatif. Data yang diperoleh dalam penelitian ini berupa data hasil observasi tentang proses pembelajaran, hasil wawancara, member check, triangulasi, dan expert opinion.

\section{Teknik Analisis Data}

Analisis data yang digunakan adalah analisis data deskriptif kualitatif. Data yang diperoleh dalam penelitian ini berupa data hasil observasi tentang proses pembelajaran, hasil wawancara dan laporan harian. Data tambahan yang diperoleh darri wawancara tidak tersutruktur dengan siswa dan dari dokumentasi foto kamera sebagai pertimbangan. Kemudian data yang diperoleh dianalisis dalam beberapa tahap sebagai berikut:

1. Analisis data hasil observasi pelaksanaan pembelajaran.

2. Data tentang keterlaksanaan pembelajaran ini dianalisis secara kuantitatif yaitu dengan cara menghitung jumlah persentase keterlaksanaan proses pembelajaran dihitung dengan rumus:

$$
\frac{\text { Skor Total }}{\text { Skor Maksimal }} \times 100 \%
$$

Untuk kriteria prosentase keterlaksanaan proses pembelajaran dan prosentase rata-rata ketuntasan belajar akan dinalisis sesuai dengan kriteria yang diadaptasi dari pedoman (Nuryadi, 2009, p.60)

Tabel 1. Persentase keberhasilan

\begin{tabular}{|c|c|c|}
\hline No & Jumlah Persen (\%) & Skor \\
\hline 1 & $0-33 \%$ & Kurang \\
\hline 2 & $34 \%-67 \%$ & Sedang \\
\hline 3 & $68 \%-100 \%$ & Baik \\
\hline
\end{tabular}

3. Reduksi data

Tahap ini dilakukan untuk merangkum data, memfokuskan pada hal-hal yang penting. Pengurangan (Reduksi) data dapat dilakukan selama tahap analisis data. Untuk pelaksanaannya, langkah ini tidak membutuhkan perhitungan yang rumit, yaitu membentuk data yang tersedia menjadi satu bentuk yang diperlukan oleh teknik analisis yang digunakan.

4. Triangulasi

Triangulasi pada penelitian ini dilakukan dengan membandingkan data hasil observasi, data hasil wawancara dengan guru dan diperkuat dengan catatan lapangan serta berupa dokumentasi fhoto.

5. Display data 
Adapun data bentuk tes atau soal evaluasi dianalisis/dihitung persentase yang digunakan untuk mengetahui prestasi belajar, dengan menggunakan rumus:

rata - rata nilai hasil tes $100 \times 100 \%$

6. Kesimpulan

Data yang diperoleh setelah dianalisis kemudian diambil simpulannya apakah tujuan dari pembelajaran sudah tercapai atau belum, apabila belum tercapai atau belum, apabila belum tercapai dilakukan tindakan selanjutnya dan apabila sudah tercapai penelitian dihentikan.

\section{Hasil Penelitian dan Pembahasan}

Data hasil penelitian

1. Hasil Observasi

Dari hasil pengamatan, diperoleh perhitungan keterlaksanaan pembelajaran pada pengamatan guru dan siswa, yaitu pada siklus I menunjukan persentase $60 \%$ pada pertemuan I, $70 \%$ pada pertemuan II, sedangkan pada siklus II terjadi peningkatan persentase pada perhitungan lembar observasi keterlaksanaan pembelajaran sebesar $76 \%$ pada pertemuan I, $85 \%$ pada pertemuan ke-2 dengan kategori "Baik".

2. Hasil Wawancara

Pertanyaan dalam pedoman wawancara terdiri dari beberapa pertanyaan diantaranya: respon siswa terhadap pembelajaran yang dilakukan sebelum menggunakan PMRI dan sesudah di terapkan PMRI, tanggapan siswa mengenai pembelajaran yang telah dilaksanakan. Untuk tanggapan siswa mengenai pembelajaran dengan pendekatan matematika realistik merasa senang karna dengan pembelajarn matematika realistik siswa jadi tahu gunanya mempelajari matematika yang disampaikan dalam kehidupan seharihari. Dengan belajar matematika relaistik siswa menjadi tahu guna dari materi yang dipelajari tidak hanya dalam benutk konsep matematis tetapi juga tahuu penggunaan konsep tersebut apabila di terapkan dalam dalam kehidupan sehari-hari mereka. Pembelajaran dengan menggunakan matematika realistik juga menekankan pembelajaran dengan cara berinteraktivitas sesuai dengan karakteristik PMRI dimana proses belajar seseorang tidak hanya suatu proses individu melainkan juga secara bersamaan merupakan suatu proses sosial. Proses belajar siswa akan menjadi lebih meningkat dan bermakna ketika siswa saling mengkomunikasikan hasil kerja dan gagasan mereka.

\section{Pembahasan Hasil Penelitian}

Berdasarkan hasil evaluasi pada pelaksanaan penelitian hasil belajar siswa, yaitu didapatkan nilai dengan persentase pra siklus (Pretesst) yaitu dengan rata-rata $62,25 \%$, siklus I $83.00 \%$, siklus II 93 , $65 \%$ maka dapat dilihat pada grafik dibawah ini.

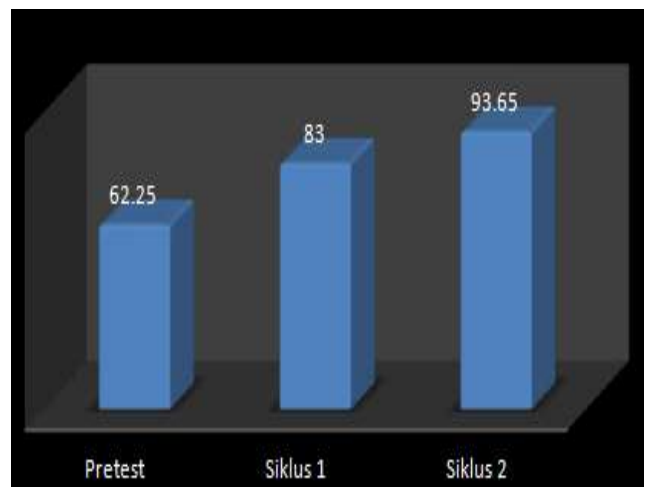

Grafik 1. Perbandingan nilai rata-rata pretest, Siklus I, siklus 2

Selain dari tes hasil belajar siswa yang telah dijabarkan diatas, didapatkan juga hasil pengamatan pembelajaran dengan pendekatan pembelajaran matematika realistik diperoleh hasil : 
Tabel 3. Rekap hasil observasi pelaksanaan pembelajaran dengan pendekatan pembelajaran matematika realistik Indonesia siklus I.

\begin{tabular}{|l|c|c|}
\hline & $\begin{array}{c}\text { Pertemuan } \\
\text { I }\end{array}$ & $\begin{array}{c}\text { Pertemuan } \\
\text { II }\end{array}$ \\
\hline $\begin{array}{l}\text { Persentase rata- } \\
\text { rata proses } \\
\text { belajar mengajar }\end{array}$ & $60 \%$ & $70 \%$ \\
& & \\
\hline
\end{tabular}

Dari tabel diatas terlihat pelaksanaan pembelajaran dengan pendekatan pembelajaran matematika realistik mengalami peningkatan sebesar $10 \%$. Untuk lebih jelasnya terlampir pada hal 170 dengan hasil persentase pada keduanya yaitu sebesar $60 \%$, berdasarkan hasil observasi termasuk dalam kualifikasi "sedang".

Tabel 2. Rekap hasil observasi pelaksanaan pembelajaran dengan pendekatan pembelajaran matematika realistik Indonesia siklus II.

\begin{tabular}{|l|c|c|}
\hline & $\begin{array}{c}\text { Pertemuan } \\
\text { I }\end{array}$ & $\begin{array}{c}\text { Pertemuan } \\
\text { II }\end{array}$ \\
\hline $\begin{array}{l}\text { Persentase rata- } \\
\text { rata proses } \\
\text { belajar } \\
\text { mengajar }\end{array}$ & $76 \%$ & $85 \%$ \\
\hline
\end{tabular}

Dari tabel diatas terlihat pelaksanaan pembelajaran dengan pendekatan pembelajaran matematika realistik siklus II mengalami peningkatan sebesar 9\%. Untuk lebih jelasnya terlampir pada hal 175 dengan hasil persentase pada keduanya yaitu sebesar $80 \%$, berdasarkan hasil observasi termasuk dalam kualifikasi "baik". Hasil ini menunjukan adanya peningkatan proses pelaksanaan pembelajaran dari siklus I ke siklus II yaitu sebesar 20\%. Peneliti menyimpulkan bahwa proses pelaksanaan pembelajaran dengan pendekatan pembelajaran matematika realistik Indonesia sudah terlaksana dengan baik.

\section{Kesimpulan}

Berdasarkan tujuan penelitian dan pembahasan, maka penelitian yang dilaksanakan di SMP Negeri 1 Seyegan, dengan subyek 32 siswa, dapat disimpulkan sebagai berikut:

1. Pembelajaran matematika pada siswa kelas VIIE SMP Negeri 1 Seyegan dengan pendekatan matematika realistik dapat meningkatkan prestasi belajar siswa, nilai rata-rata siswa telah meningkat diatas keriteria ketuntasan yag telah ditetapkan sekolah yaitu $\geq$ 75, hasil belajar siswa pada setiap siklusnya mengalami peningkatan meskipun ada sebagian yang menurun nilainya pada siklus I dia mendapatkan nilai tinggi dan siklus 2 nya menurun, tetapi penurunan tersebut secara signifikan masih diatas keriteria ketuntasan. Hal tersebut secara kuantitatif ditunjukan dari perhitungan lembar observasi keterlaksanaan pembelajaran, yaitu pada siklus I menunjukan persentase $60 \%$ pada pertemuan I, $70 \%$ pada pertemuan II, sedangkan pada siklus II terjadi peningkatan persentase pada perhitungan lembar observasi keterlaksanaan pembelajaran sebesar $76 \%$ pada pertemuan I, 85\% pada pertemuan ke-2.

2. Hasil belajar siswa dengan menggunakan pendekatan Pembelajaran Matematika Realistik Indonesia (PMRI) meningkat dari siklus I ke siklus II. Hal ini dapat dilihat dari hasil nilai rata-rata evaluasi siklus I sebesar $82,31 \%$ dengan kategori baik dan siklus II 92,31 dengan kategori baik.

\section{Saran}

Dengan adanya berbagai paparan kesimpulan diatas, peneliti memberikan saran tentang implementasi pendekatan Pembelajaran Matematika Realistik Indonesia (PMRI) sebagai pertimbangan, yaitu: 
1. Dalam pemeblajaran harapannya guru dapat menyediakan alat peraga berupa benda-benda konkrit yang cukup dan disesuaikan dengan materi yang dipelajari supaya memudahkan siswa mengkontruksi konsep dan memudahkan siswa dalam memahami materi.

2. Keterlaksanaan pendidikan realistik memerlukan kesiapan banyak pihak yang terkait dalam pembelajaran, misalnya dengan memiliki pengetahuan yang luas tentang pendidikan realistik, penggunaan alat peraga, Lembar Kerja Siswa (LKS), dsb.

3. Untuk jumlah kelas yang besar hendaknya disiasati guru dengan cara sering mengadakan pembelajaran melalui diskusi keelompok sehingga interaksi antarsiswa lebih mendominasi dalam pembelajaran.

\section{Daftar Pustaka}

Agus Suprijono. 2009. "Coopperative learning teori dan aplikasi PAIKEM”. penerbit: Yogyakarta; Pustaka pelajar.

A. M Slamet Soewandi. 2005. "Perspektif pembelajaran berbagai bidang studi" Yogyakarta" Universitas Sanata Darma

Ariyadi Wijaya. 2012. "Pendidikan Matematika Realistik Suatu Alternatif Pembelajaran Matematika”. Yogyakarta: Graha Ilmu.

Armanto, D. 2002. "Teaching multiplication and divisio realistically in Indonesian primary schools: A Prototype of local Instructional (Diss". Enschede: PrintPartners Ipskamp.

Depdiknas, "Undang-undang pendidikan sistem http://www.inharent- dikti.net/files/sisdiknas.pdf (Diakses hari: Rabu, Pkl. 11:23 26 November 2014).

Fadjar Shadiq dan Nur Amini Mustajab. 2010. "Pembelajaran matematika dengan pendekatan realistik di SMP”. Jakarta: Kemendiknas.

Gravemeijer, K. (1994) "Developing Realistic Mathematics Education Utrecht" Freudenthal Institute.

Hananto Wibowo. "Perbandingan efektivitas pembelajaran matematika dengan pendekatan konvensional pada materi prisma dan luas ditinjau dari hasil prestasi belajar siswa Kelas VIII SMP Negeri 2 Depok Yogyakarta”. Skripsi. Program Studi Pendidikan Matematika Fakultas Matematika dan Ilmu Pengetahuan Alam Universitas Negeri Yogyakarta, 2010.

R. Soedjadi. 2000. "Kiat pendidikan matematika di Indonesia”. Surabaya : Departemen Pendidikan Nasional.

Muhammad Irham \& Novan Ardy Wiyani. 2013. "Psikologi pendidikan teori dan aplikasi dalam proses pembelajaran”. Yogyakarta: ArRuzz Media.

Van den Heuvel-Panhuizen, M. (1996). "Assessment and Realistic Mathematics Education" Utrecht: Freudental Institute.

Zainal Aqib. 2008 "Penelitian Tindakan Kelas". Bandung: CV. Yrama Widya 